\title{
Urban Soil Pollution with Heavy Metals in Hama Floodplain, Syria
}

\author{
Hussam H. M. Husein ${ }^{1}$, Mouhiddin Kalkha ${ }^{2}$, Ahmad Al Jrdi ${ }^{3}$, Rupert Bäumler ${ }^{1}$ \\ ${ }^{1}$ FAU Erlangen-Nuremberg University, Institute of Geography, Germany \\ ${ }^{2}$ General Commission for Scientific Agricultural Research, Damascus, Syria \\ ${ }^{3} \mathrm{Al}$ Baath University, Faculty of Agriculture, Department of Soil and Land Reclamation, Syria \\ Email: *hussam.husein@fau.de
}

How to cite this paper: Husein, H.M., Kalkha, M., Al Jrdi, A. and Bäumler, R. (2019) Urban Soil Pollution with Heavy Metals in Hama Floodplain, Syria. Natural Resources, 10, 187-201.

https://doi.org/10.4236/nr.2019.106013

Received: April 18, 2019

Accepted: June 24, 2019

Published: June 27, 2019

Copyright $\odot 2019$ by author(s) and Scientific Research Publishing Inc. This work is licensed under the Creative Commons Attribution International License (CC BY 4.0).

http://creativecommons.org/licenses/by/4.0/

\begin{abstract}
The Orontes river basin can be considered one of the most polluted areas in the eastern Mediterranean due to the intense urban occupation, intensive agriculture irrigation, and large numbers of different industries activities. The objective of the study was to assess the extent and severity of heavy metal pollution of arable soils of Hama floodplain, in order to provide a general insight vision of pollution status in this intensive agricultural production area. The present and spatial distribution of four heavy metals $(\mathrm{Cd}, \mathrm{Cu}, \mathrm{Pb}, \mathrm{Zn})$ concentration have been examined in 5 monitoring sites of river's water along the part of the river passing through the plain of Hama; and also from 93 samples of topsoil from the area surrounding the city of Hama have been examined. The concentrations of heavy metals in both river water and soil were within the international standards. Water analyses indicated $\mathrm{pH}$ of moderately alkaline, no irrigation problem related to ammonium nitrogen and phosphate phosphorus, while the Electrical Conductivity (EC) has referred to an increasing problem. Geo-accumulation Index (Igeo) refers to strong building up for $\mathrm{Cd}, \mathrm{Pb}$, and very strongly for $\mathrm{Cu}$. Soil analyses refer to clayey, calcareous, and alkaline soil with $\mathrm{pH}$ ranges from 7.5 to 8.6 , with significantly higher organic matter content especially near sewage plants, attributed to irrigation with untreated sewage sludge water. Geostatistical analysis of data showed up normal spatial distribution related to the high variation between the values of the studied elements; whereas the $\mathrm{Cu}$ and $\mathrm{Cd}$ concentrations were higher than allowable limit near the steel, rubber wheel factories and reach 127 for $\mathrm{Cu}$ and $9.8 \mu \mathrm{g} \cdot \mathrm{g}^{-1}$ for Cd. Additionally, a high concentration of $\mathrm{Cu}$ was significantly associated with organic matter content. The concentration of $\mathrm{Pb}$ was within the limits, with the exception of riverbanks where the values of $\mathrm{Pb}$ exceed 95 $\mu \mathrm{g} \cdot \mathrm{g}^{-1}$, with (Igeo) of 4.22 refers strongly to very strong accumulation. Total $\mathrm{Zn}$ concentration showed higher variability and values ranging from 13 to 760 $\mu \mathrm{g} \cdot \mathrm{g}^{-1}$, with a distribution trend increases from southeast to northwest. However, its environmental risk will be more serious to human and livestock.
\end{abstract}




\section{Keywords}

Pollution, Heavy Metal, Geo-Accumulation Index, Enrichment Factor, Geostatistical Analyses, Orontes Basin

\section{Introduction}

Soil pollution refers to the presence of chemical or substance out of place and/or present at higher than the normal concentration that has adverse effects on any non-targeted organism [1], and poses an increasing threat to human health and environmental quality [2]. Industrialization, wars, mining, and intensification in agriculture have left a legacy of contaminated soils around the world [3] [4] [5] [6] [7]. The term "heavy metals" refers to the group of metals and metalloids which are naturally occurring in soil [8], and relatively high atomic mass ( $>4.5$ $\mathrm{g} / \mathrm{cm}^{3}$ ) such as $\mathrm{Pb}, \mathrm{Cd}, \mathrm{Cu}, \mathrm{Hg}, \mathrm{Sn}$, and $\mathrm{Zn}$, that can cause toxicity problems [9] [10] [11] [12]. Their concentrations increased by geological and anthropogenic activates, the metal from anthropogenic tend to be more mobile than those from pedogenic or lithogenic sources [13] such as the excess use of agrochemicals [14], sewage sludge and municipal waste disposal [15] [16]. Soil contamination with heavy metals Sprawls in many regions of the world [17] [18] [19] [20]. Unlike organic contaminants, heavy metals cannot be degraded [21] [22] and easy to contaminate the food chain [23] [24] [25]. Soil can easily be polluted by heavy metal from many sources, such as atmospheric deposition, sewage irrigation, improper stacking of the industrial solid waste, mining activities, the use of pesticides and fertilizers [26] [27]. Globally, 80 percent of municipal wastewater is discharged into water bodies untreated, and industry is responsible for dumping millions of tonnes of heavy metals, solvents, toxic sludge and other wastes into water bodies each year [28]. Agriculture, which accounts for 70 percent of water abstractions worldwide, plays a major role in soil pollution, as the use of industrial or municipal wastewater in agriculture is a common practice in many parts of the world. Fifteen years ago, at least 20 million hectares in 50 countries were irrigated with un- or partially treated wastewater [29] [30]. In fact, wastewater use varies considerably from one region to another, in Hanoi, Vietnam, for instance, up to 80 percent of vegetables produced are irrigated with wastewater [31]. Irrigation plays a crucial role in agriculture in arid and semi-arid climate zones [32], it is very important for food security. In zones where annual precipitation was insufficient for rain-fed agriculture, such as the areas with a Mediterranean climate in the Near East, irrigation could make a major economic difference [32]. In Orontes basin, the accelerated demand for water pushes local farmers to use non-conventional water for irrigation as the sources of fresh water became short. The non-conventional water in last decades becomes more polluted because of climate change, population growth, and increasing of human activities. Wastewater irrigation has opposite aspects; beneficial which providing 
a reliable source of water supply, when the availability of good quality water becomes scarce [33], its reliability in arid areas [34] [35], adding valuable plant nutrients and organic matter to soil [36] [37]. Despite these advantages, it has detrimental aspect where it can profoundly affect the soil moisture, aeration regime, surface properties, biological activity, toxic chemicals like heavy metals and pesticides in the water [36] and many other environmentally important functions of the soil system. The use of treated and non-treated wastewater for agricultural irrigation, which is rich in heavy metal, is common in arid and semiarid regions as a solution to water scarcity [38] [39] [40]. Although soil often acts as a filter, purifying and immobilizing many of the impurities deposited in it, its capacity is limited. The cumulative effects of atmospheric pollutants, agrochemicals and fertilizers, industrial and domestic solid residues, and toxic and radioactive materials, can negatively affect the soil [41]. Some Soil properties affected metal availability such as soil $\mathrm{pH}$ [42], moisture content and water holding capacity [43]. Soil contamination with heavy metals may also cause changes in the composition of soil microbial community, adversely affecting soil characteristics [44] [45] [46] [47]. On the other hand, the mobility of heavy metals is slow in clayey alkaline soils with a high content of calcium carbonate and their utility is limited due to immobilization [48].

Geostatistical methods are often used for prediction mappings of soil properties, because it can calculate unbiased estimates at un-sampled locations [49]-[54]. Since pollution in soil presents a continuum in their spatial variations, geostatistical methods are widely used to display this variation and to reduce costs of investigation and to recognize the contamination on sources [55] [56] [57]. The aims of this study are: 1) to investigate the contents of four heavy metal $(\mathrm{Cu}, \mathrm{Zn}, \mathrm{Cd}$ and $\mathrm{Pb})$ in both river water and soil of pilot area of Orontes basin, 2) to characterize the spatial distributions of this heavy metal, 3) to provide an insight into possible heavy metal contamination by generation of the predicted maps.

\section{Study Area}

The study area: The Orontes basin is an important agricultural area of irrigated land in Midwest of Syria, with a total area of $23,967 \mathrm{~km}^{2}$, extended from NE of Lebanon through Syria to the South of Turkey. Orontes basin plays an important role in the agriculture economy of Syria, whereas irrigated winter wheat, sugar beet and cotton are growing depending mainly on Orontes river water, which is highly polluted by both domestic sewerage and sludge sewerages [58]. Orontes river is considered one of the most polluted rivers in the eastern Mediterranean due to high evapotranspiration, a large number of different industries and lack of sewage water treatment plants.

The area of Orontes basin extended around Hama city (northwest to the southwest) was chosen as a pilot area $35.05-35.20 \mathrm{~N}$ and $36.85-36.67 \mathrm{E}$. The area is characterized by intensive agricultural and industrial activity, and includes the city of Hama and its environs and residential communities in Ghor 
Al-Assi, Genan Al-Asi, Sreiheen, Al Daheria, Kazo, Shirraaya, Barza, and Khattab (Figure 1).

In recent decades, agricultural intensification has occurred in parallel with industrial (Metallurgical and Chemical) and urban expansion; these exert a high pressure on the soils and could result in contamination. Agricultural practices used in this area, such as the intensive use of agrochemical products and wastewater, for soil irrigation, result in contamination that requires in-depth investigation. In addition, the concentration of industrial areas near villages and the presence of small industries in the agricultural zones could increase the concentration of pollutants, which should be re-assessed.

The land-use patterns are typical and representative of Mediterranean semiarid climate with $342 \mathrm{~mm}$ precipitation, maximized in winter and $19.3^{\circ} \mathrm{C}$ annual temperature. The summer is hot dry in which the evapotranspiration exceeds precipitation, with 144 dry days starting from 25 May to 15 of October (Figure 2). According to aridity index, most of the area is dry, which suggests huge demand for water for irrigation.

\section{Materials and Methods}

\subsection{Field Work and Data Collection}

In order to provide an insight into possible heavy metal contamination that may be occurring in the study area, the spatial distribution of heavy metal has been mapped for the pilot area using data from river water and soil samples, the data were interpolated using ordinary kriging and prediction mappings of polluted areas were generated.

Water samples have been taken in the irrigation session along the flow of the Asi River from the southeast to the northwest from five monitoring sites ( $\mathrm{Al}$ Gassalat, Genan Al Asi, Al ArbaaNawheer, Al Daheria, and Arza). Bulk soil samples of 93 observation sites were collected from $30 \mathrm{~cm}$ of the plow layer and from $30-60 \mathrm{~cm}$ of the subsoil; the data from the last depth did not present in this study. The grid net survey of $0.5 \mathrm{~km}$ intervals was conducted (60 grid SE, 60 grid NW) (Figure 3).

Location coordinates for all sampled sites were determined using Global Positioning System (GPS) where data are to be used by Geographical Information System (GIS) for data processing. Before analysis, the soil samples were drying in an oven at $50^{\circ} \mathrm{C}$ for overnight, grounded finely and sieved through a $63 \mu \mathrm{m}$ plastic sieve. Analyses of total content of heavy metals $(\mathrm{Cd}, \mathrm{Pb}, \mathrm{Zn}, \mathrm{Cu})$ were performed by using the high quality concentrated $(70 \% \mathrm{w} / \mathrm{v})$ nitric acid, hydrogen peroxide $(35 \%)$ and hydrochloric acid $(38 \%)$. the samples were placed in Teflon tubes and digested with $\mathrm{HNO}_{3}, \mathrm{HF}$, and $\mathrm{HClO}_{4}$. Then the solutions were diluted with $2 \%(\mathrm{v} / \mathrm{v}) \mathrm{HNO}_{3}$ to a final volume of $50 \mathrm{ml}$, and then the samples were analyzed using an atomic absorption spectrophotometer. Particle-size distribution of bulk soil was determined by the sieve-hydrometer method [59]. The organic carbon content in fine earth was determined by dichromate oxidation [60]. The soil $\mathrm{pH}$ was determined in 1:2 soil/water solution. 

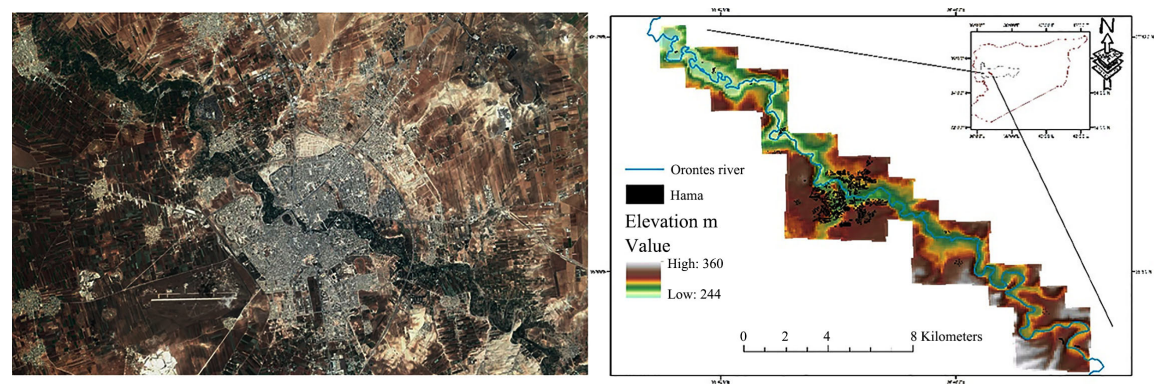

Figure 1. Location of the study area.

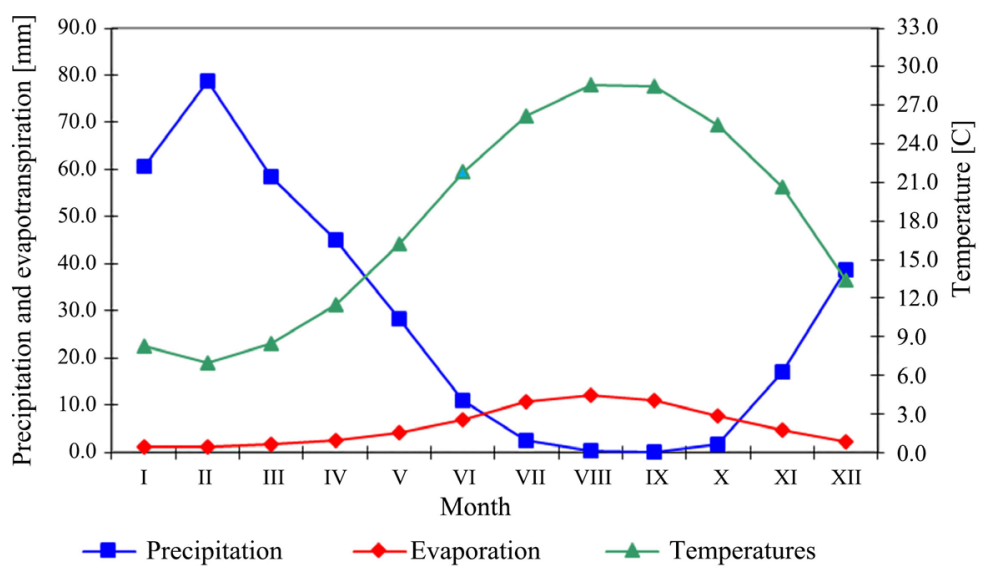

Figure 2. Ombrothermic diagrams of Hama metrological station.

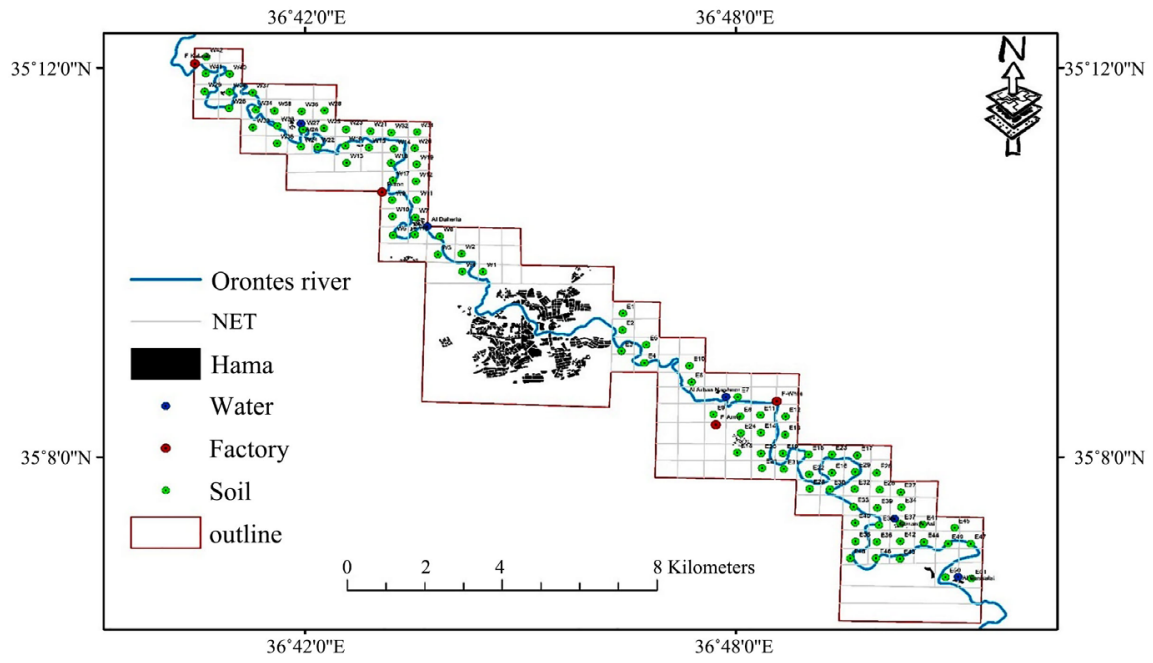

Figure 3. The grid net of water and soil sampling.

\subsection{Pollution Assessment}

By applying Geo-accumulation Index (Igeo) [61],

$$
\text { Igeo }=\log 2\left(\frac{\mathrm{Cn}}{1.5 \cdot \mathrm{Bn}}\right)
$$

where $\mathrm{Cn}$ is the measured content of an element, and $\mathrm{Bn}$ is the background or pristine value of the element. The numerical results are indicative of different 
pollution classes. The degree of metal pollution is assessed in terms of seven contamination classes based on the increasing numerical value of the index as follows: [62].

- I-geo $<0$ means unpolluted

- $0 \leq \mathrm{I}$-geo $<1$ means unpolluted to moderately polluted

- $1 \leq$ I-geo $<2$ means moderately polluted

- $2 \leq$ I-geo $<3$ means moderately to strongly polluted

- \& $3 \leq$ I-geo $<4$ means strongly polluted

- $\& 4 \leq$ I-geo $<5$ means strongly to very strongly polluted

- \& I-geo $\geq 5$ means very strongly polluted.

Enrichment Factor (EF) to assess the presence and intensity of anthropogenic contaminant deposition on surface soil [63],

$\mathrm{EF}=($ Metal $/ \mathrm{RE})$ soil/(Metal/RE) background

Where RE is the value of metal, adopted as Reference Element. The five contamination categories are recognized on the basis of the enrichment factor as follows [64]:

- $\mathrm{EF}<2$ is deficiency to minimal enrichment

- $\mathrm{EF}=2-5$ is moderate enrichment

- $\mathrm{EF}=5-20$ is significant enrichment

- $\mathrm{EF}=20-40$ is very high enrichment

- $\mathrm{EF}>40$ is extremely high enrichment

\subsection{Pollution Mapping}

Geostatistical analyses were applied through the analysis of semivariograms of the selected individual variables. Experimental semivariograms were obtained from the omnidirectional semivariances, $\gamma(\mathrm{h})$, as a set of spatial observations, $Z\left(x_{i}\right)$, which were calculated as:

$$
\gamma(h)=\frac{1}{2 N(h)} \sum_{i=1}^{N(h)}\left[z\left(x_{i}\right)-z\left(x_{i}+h\right)\right]^{2}
$$

where: $z\left(x_{i}\right)$ and $z\left(x_{i}+h\right)$ are experimental measures of any two points separated by the vector $h$, and $N(h)$ is the number of experimental pairs separated by $h$. In practice, a semivariogram simply enumerates the relationship between the degree of similarity between two measurements of some variable $Z\left(x_{i}\right)$ separated by distance $h$, which is termed the lag.

\section{Results and Discussion}

\subsection{Pollutants in the River's Water}

The Physicochemical parameters and heavy metal concentrations of Orontes river water were shown in Table 1.

The water $\mathrm{pH}$ is indicating moderately alkaline nature, while the Electrical Conductivity (EC) has referred to increasing problem. There was no irrigation problem related to ammonium nitrogen and phosphate phosphorous. 
Table 1. Chemical analysis of Orontes River Water.

\begin{tabular}{cccccccc}
\hline Observation point & $\mathrm{pH}$ & $\begin{array}{c}\mathrm{EC} \\
\mathrm{ms} \cdot \mathrm{cm}^{-1}\end{array}$ & $\begin{array}{c}\mathrm{NH} 4-\mathrm{N} \\
\mathrm{mg} \cdot \mathrm{l}^{-1}\end{array}$ & $\begin{array}{c}\mathrm{PO} 4-\mathrm{P} \\
\mathrm{mg} \cdot \mathrm{l}^{-1}\end{array}$ & $\begin{array}{c}\mathrm{Pb} \\
\mu \mathrm{g} \cdot \mathrm{g}^{-1}\end{array}$ & $\begin{array}{c}\mathrm{Cd} \\
\mu \mathrm{g} \cdot \mathrm{g}^{-1}\end{array}$ & $\begin{array}{c}\mathrm{Cu} \\
\mu \mathrm{g} \cdot \mathrm{g}^{-1}\end{array}$ \\
\hline Al Gassalat & 7.9 & 0.82 & 0.58 & 6 & 0.35 & 0.091 & 0.55 \\
Genan Al Asi & 7.8 & 0.86 & 0.7 & 7.37 & 0 & 0.079 & 0.22 \\
Al Arbaa Nawheer & 7.5 & 0.79 & 0.38 & 3.5 & 0 & 0.084 & 0.15 \\
Al Daheria & 7.6 & 0.87 & 0.7 & 5.5 & 0.08 & 0.086 & 0.35 \\
Brza & 7.22 & 0.87 & 1.8 & 6.8 & 0.14 & 0.103 & 0.73 \\
EPA Standard & $6.5-8.4$ & $0.7-3.0$ & - & - & 5.0 & 0.01 & 2.0 \\
\hline
\end{tabular}

According to Geo-accumulation Index $\left(I_{\text {geo }}\right)$, the concentration of heavy metal denoted a moderately to strong pollution for $\mathrm{Cd}$ and $\mathrm{Pb}$, and very strongly pollution for $\mathrm{Cu}$, which is higher of [65] recommended threshold. Although the index is for sediment, it gives the indication that accumulation will increase in soils when the soil is irrigated with such irrigation water

\subsection{The Physicochemical Properties of the Soil}

The $\mathrm{pH}$ and organic matter content of the soils are very important factors in controlling mobility and concentration of elements in the soils. The $\mathrm{pH}$ values ranged from 7.5 to 8.6 (Figure 4). The results indicate that the soils within the study area are alkaline; (higher $\mathrm{pH}$ values) not favor the availability of cations in soil [66]. That might be explained by the calcareous origin of the parent material as the soil total calcium carbonate content ranging from $23 \%$ to up $44 \%$. The Organic matter (OM) content in soil showed high value comparing to soil existing in the area, ranging from less than $1 \%$ to $9.8 \%$ (Figure 4 ).

The higher content near sewage stations supports the idea of higher content due to direct irrigation with sewage sludge water, and this indicates that metals are more likely to be bound to organic matter to form metal-chelate complexes, and this would also result in less availability of metals to plants [67] [68].

Clay content is high (clay ranges from $12 \%$ to more than $40 \%$ ) and the soil has clay loam to clayey texture. This may be the result of continuous deposition of alluvium on the riverbed in Orontes River (Figure 5).

The absence of clay migration process is a result of continuous soil cultivating and extensive agriculture rotation. In addition, oxidation and terraces of redox-morphic features observed, this is related to irrigation method (flood irrigation) applying by local farmers.

Clayey and high calcium carbonate soil gives the area a high potential for adsorption of heavy metals.

\subsection{Soil Heavy Metals Concentration and Distribution}

The spatial variations of heavy metal in soils were more significant than that in river water. Geostatistical analysis showed that data did not well-distributed because of the high variation between the studied elements data. 

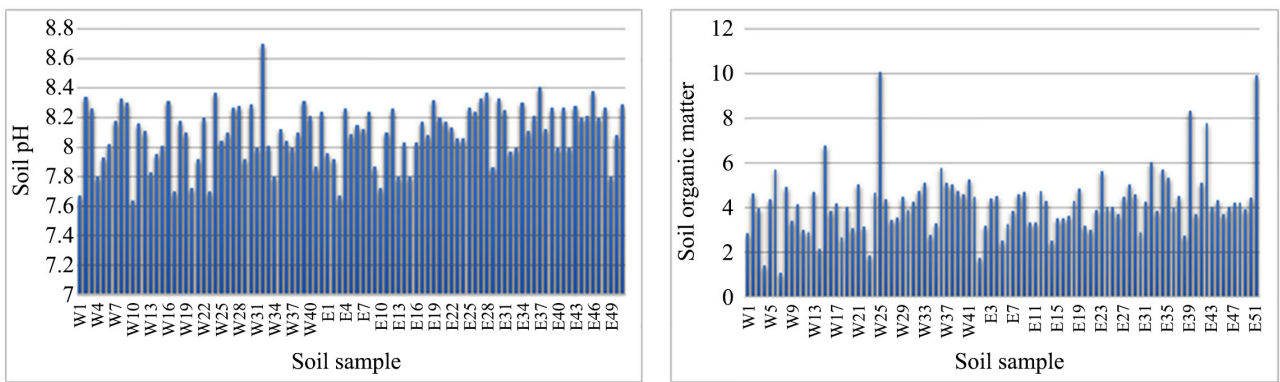

Figure 4. The soil $\mathrm{pH}$ and Organic matter (OM) content.

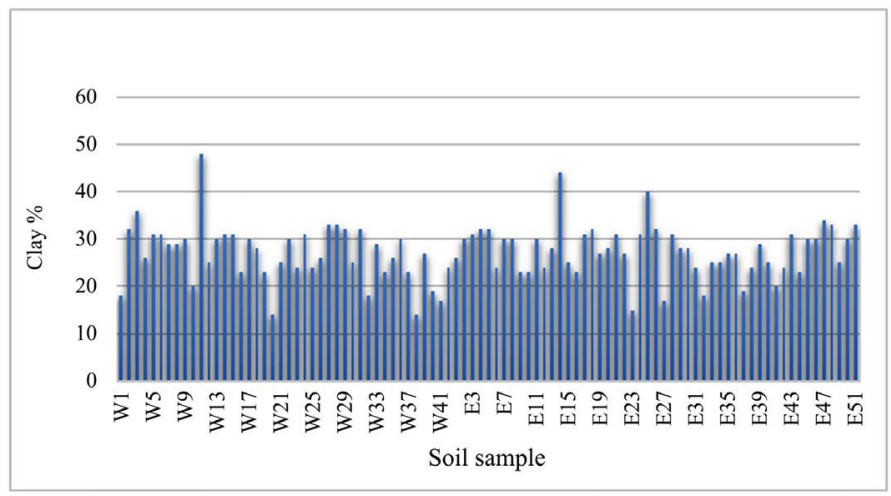

Figure 5. The soil clay content.

The $(\mathrm{Cu})$ concentrations were high in some area ( $\mathrm{Al}$ Dahreah, near the steel factory and $\mathrm{Al}$ Genan) and reach to $127 \mu \mathrm{g} \cdot \mathrm{g}^{-1}$ (Figure 6), which is higher than allowable limit of heavy metal concentration in soil (Germany 40.0, and the USA $\left.75.0 \mu \mathrm{g} \cdot \mathrm{g}^{-1}[69]\right)$. In addition, a high concentration of $(\mathrm{Cu})$ was significantly associated with organic matter content. However, as $(\mathrm{Cu})$ is considered more readily soluble. The (I geo) was 1.49 refers to moderate pollution, and (EF) was 4.24 refers to moderate enrichment.

The highest concentrations of (Cd) (9.8) $\mu \mathrm{g} \cdot \mathrm{g}^{-1}$ were near Zourblehassenand near Srehen, where Steel and Wheel factories exist (Figure 7) (Germany 1.0, and the USA $\left.1.9 \mu \mathrm{g} \cdot \mathrm{g}^{-1}\right)$. The ( $\mathrm{g} g e \mathrm{o}$ ) was 6.64 refers to very strongly pollution, and (EF) was 6.64 refers to significant enrichment. The spatial distribution of Cdwas irregular; it may be that is the result of land use and land management (irrigated, rainfed) and the irrigation method.

The concentration of $(\mathrm{Pb})$ was in general within the limits, except for riverbanks where the values were higher, in some site like Al Dahrieh, Sraheen, and Khattab the values exceeded $95 \mu \mathrm{g} \cdot \mathrm{g}^{-1}$ (Figure 8) (Germany 40.0, and the USA $\left.15.0 \mu \mathrm{g} \cdot \mathrm{g}^{-1}\right)$. The (I geo) was 4.22 refers strongly to very strongly pollution, and (EF) was 3.5 refers to moderate enrichment.

The high concentrations of Pbin some points are due to the indiscriminate firing of solid household rubbish (dry batteries) and the presence of paint manufacturing workshops.

Total $(\mathrm{Zn})$ concentration was higher variability and values ranged from 13 to 
$760 \mu \mathrm{g} \cdot \mathrm{g}^{-1}$, its environmental risk will be more serious (Figure 9) (Germany 150.0 , and USA $140.0 \mu \mathrm{g} \cdot \mathrm{g}^{-1}$ ). The ( $\mathrm{Igeo}$ ) was 4.7 refers strongly to very strongly pollution, and (EF) was 6.6 refers to significant enrichment. The high concentrations of $\mathrm{Zn}$ at Jinan and Arza sites, explained by the existing of sewage treatment plant, while a significant increase in values was found even to the depth of $60 \mathrm{~cm}$ in Al Dahreah, near the sewage station. The spatial distributions of $\mathrm{Zn}$ concentrations in soil were un-regular; the higher concentration near riverbanks than in the rest soils could be the result of periodical waterlogging and the long period of water stagnation near riverbanks.

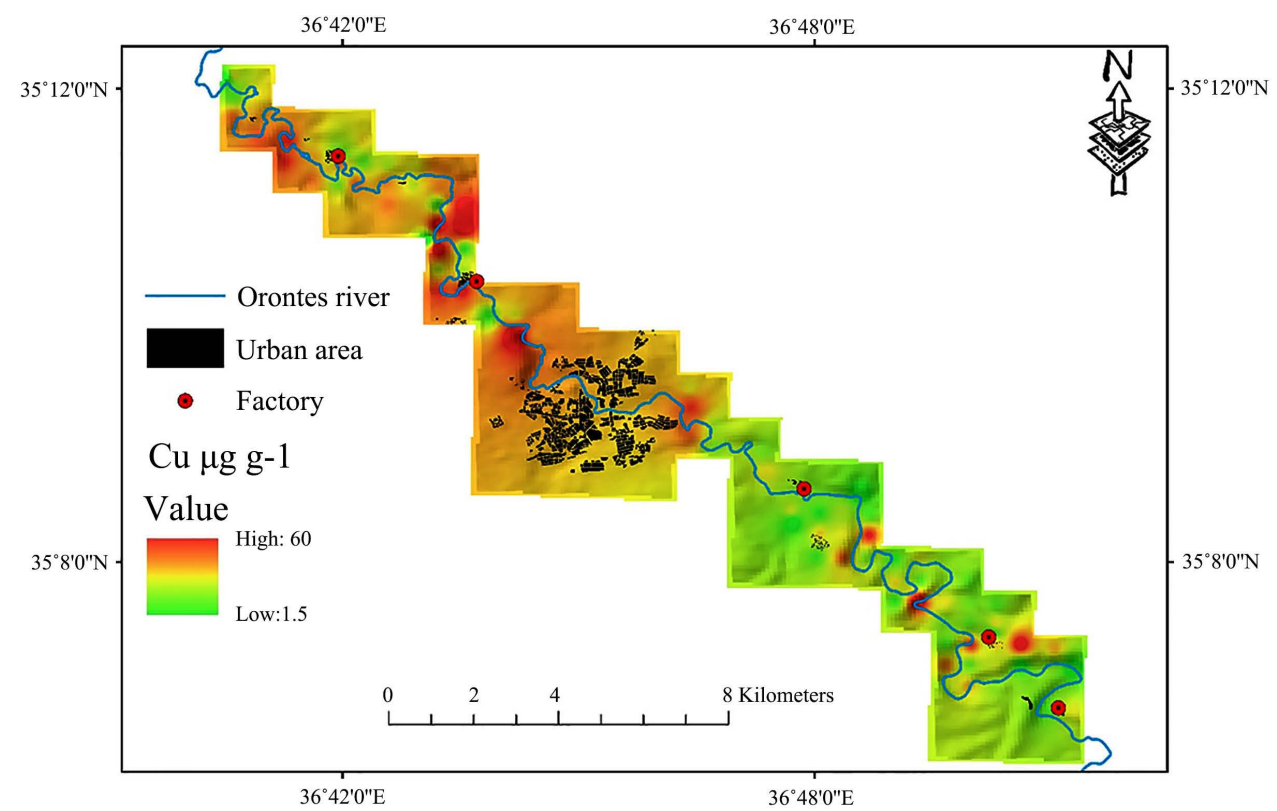

Figure 6. Spatial distribution of $\mathrm{Cu}$ concentration in the upper soil layer.

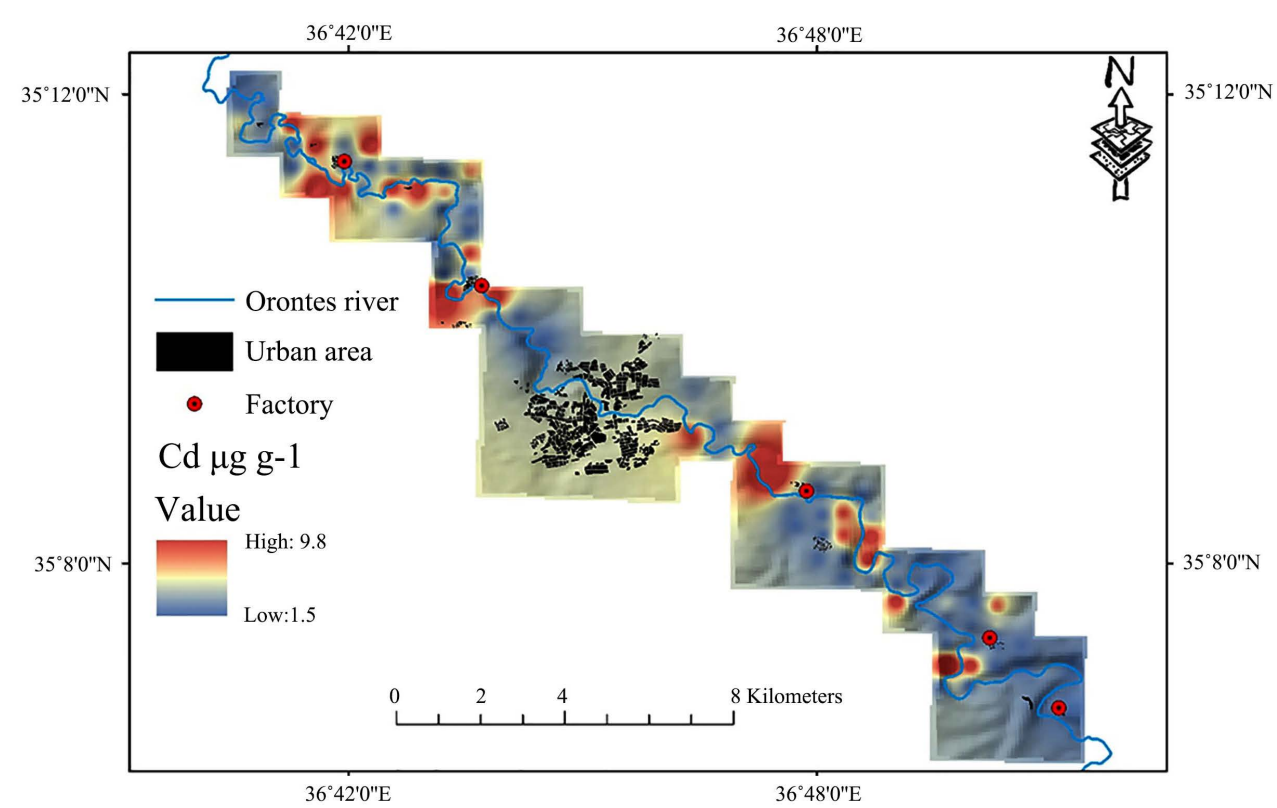

Figure 7. Spatial distribution of Cd concentration in the upper soil layer. 


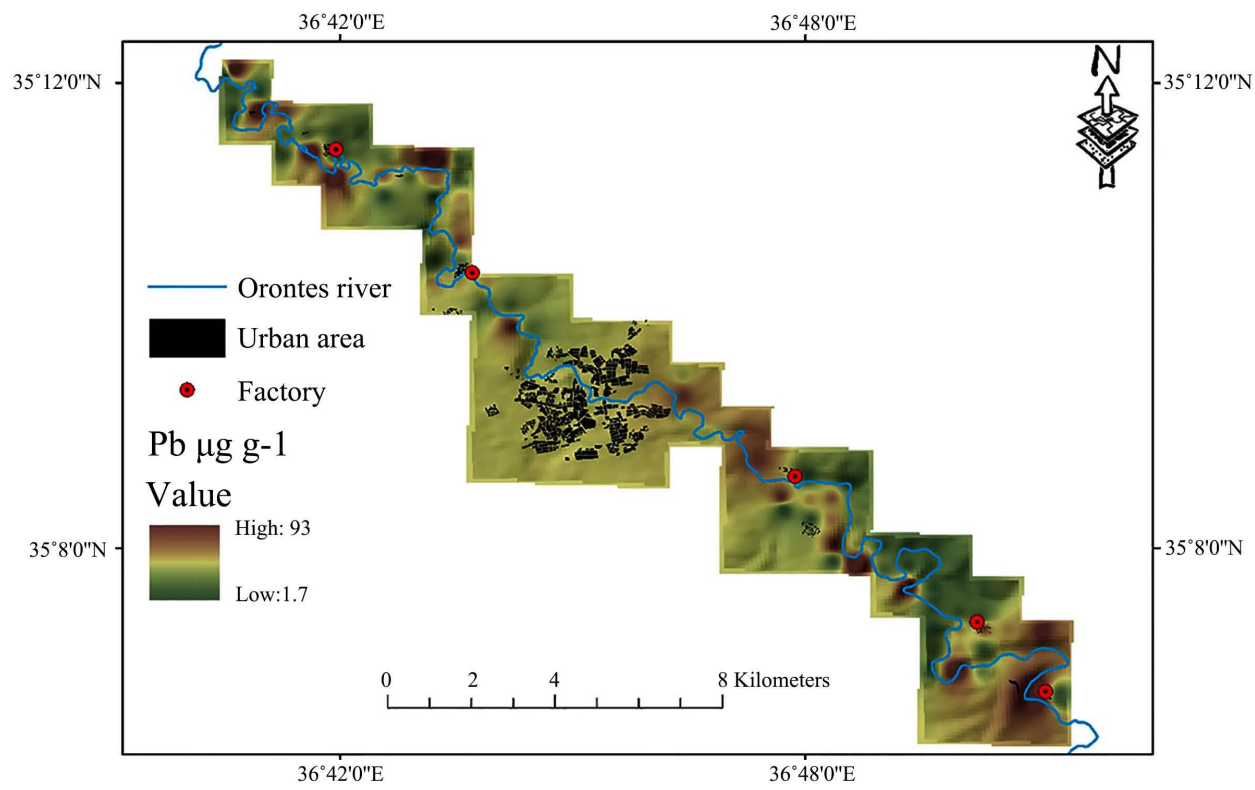

Figure 8. Spatial distribution of $\mathrm{Pb}$ concentration in the upper soil layer $(\mathrm{Pb})$.

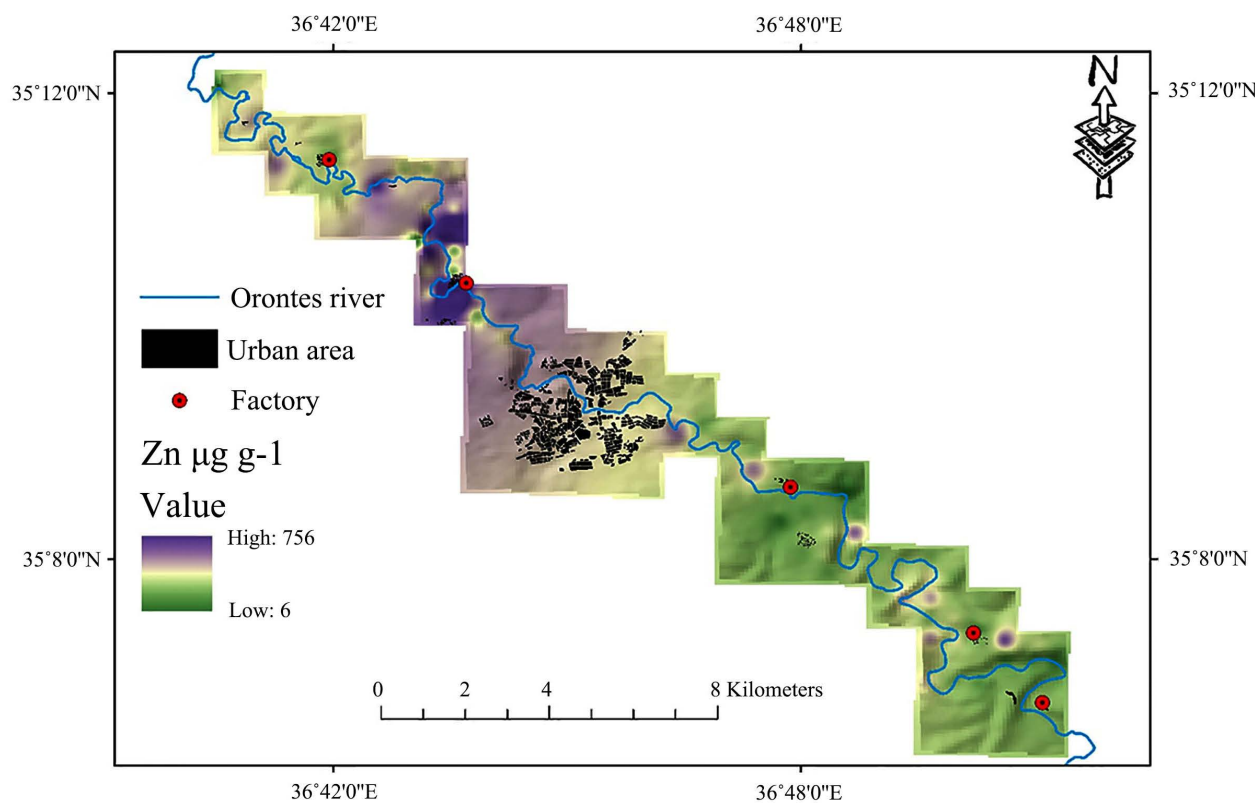

Figure 9. Spatial distribution of $\mathrm{Zn}$ concentration in the upper soil layer.

\section{Conclusions}

Mapping of four heavy metals $(\mathrm{Cd}, \mathrm{Cu}, \mathrm{Pb}$, and $\mathrm{Zn})$ in middle Orontes basin gave a comprehensive view and saved time, labor and money consuming, and showed a significant accumulation of studied elements in both river water and surrounding soil. The concentration of four heavy metals was higher in soil samples nearby center area than that in boundary samples except for $\mathrm{Zn}$. The spatial distribution of $\mathrm{Cu}$ and $\mathrm{Pb}$ concentrations in soil was irregular; while as the $\mathrm{Cu}$ was preferentially found in the soil with high organic matter content. These results require constant monitoring and identification of these pollutants 
accurately so that pollution can be prevented and heavy metals can be disposed of. The correlations for these heavy metals are related to the geographical distributions in the study area, indicating a trend of spatial concentrations increasing with the direction of river flow from southeast to northwest.

\section{Acknowledgements}

The research was funded by the Philip Schwarz Initiative. Many thanks to the Hama Center for Agricultural Scientific Research for conducting laboratory analyzes.

\section{Conflicts of Interest}

The authors declare no conflicts of interest regarding the publication of this paper.

\section{References}

[1] FAO and ITPS (2015) Status of the World's Soil Resources (SWSR)-Main Report. Food and Agriculture Organization of the United Nations and Intergovernmental Technical Panel on Soils, Rome, Italy. http://www.fao.org/3/a-i5199e.pdf.

[2] Lourenço, R.W. and Landim, P.M.B. (2005) Risk Mapping of Public Health through Geostatistics Methods. Public Health Reports, 21, 150-160.

[3] Luo, Y., Wu, L., Liu, L., Han, C. and Li, Z. (2009) Heavy Metal Contamination and Remediation in Asian Agricultural Land. National Institute for Agro-Environmental Sciences.

http://www.naro.affrc.go.jp/archive/niaes/marco/marco2009/english/program/S-1_ LuoYM.pdf

[4] DEA (2010) Framework for the Management of Contaminated Land. Republic of South Africa, Department of Environmental Affairs.

http://sawic.environment.gov.za/documents/562.pdf

[5] SSR (2010) Soil Contamination in West Africa. Environmental Remediation Pollution.

https://www.scribd.com/doc/71599035/SoilContamination-in-West-Africa

[6] Bundschuh, J., Litter, M.I., Parvez, F., Román-Ross, G., Nicolli, H.B., Jean, J.S., Liu, C.W., López, D., Armienta, M.A., Guilherme, L.R.G., Cuevas, A.G., Cornejo, L., Cumbal, L. and Toujaguez, R. (2012) One Century of Arsenic Exposure in Latin America: A Review of History and Occurrence from 14 Countries. The Science of the Total Environment, 429, 2-35. https://doi.org/10.1016/j.scitotenv.2011.06.024 http://www.sawic.environment.gov.za/documents/562.pdf

[7] EEA (2014) Progress in Management of Contaminated Sites. European Environment Agency. Management of Contaminated 1.

https://www.eea.europa.eu/data-and-maps/indicators/progress-in-management-ofcontaminated-sites

[8] Franssen, H., Eijnsbergen, A.C. and Stein, A. (1997) Use of Spatial Prediction Techniques and Fuzzy Classification for Mapping Soil Pollutants. Geoderma, 77, 243-262. https://doi.org/10.1016/S0016-7061(97)00024-4

[9] Raskin, I., Kumar, P.B.A.N., Dushenkov, S. and Salt, D.E. (1994) Bioconcentration of Heavy Metals by Plants, Current Opinion in Biotechnology, 5, 285-290. https://doi.org/10.1016/0958-1669(94)90030-2 
[10] Kemp, D.D. (1998) The Environment Dictionary. Routledge, London, New York.

[11] Bos, R., Carr, R. and Keraita, B. (2010) Assessing and Mitigating Wastewater-Related Health Risks in Low-Income Countries: An Introduction. In: Drechsel, P., Scott, C.A., Raschid-Sally, L., Redwood, M. and Bahri, A., Eds., Wastewater Irrigation and Health: Assessing and Mitigation Risks in Low-Income Countries, Earthscan-IDRC-IWMI, UK, 29-47.

[12] Tóth, G., Hermann, T., Da Silva, M.R. and Montanarella, L. (2016) Heavy Metals in Agricultural Soils of the European Union with Implications for Food Safety. Environment International, 88, 299-309. https://doi.org/10.1016/j.envint.2015.12.017

[13] Shakeri, A., Moore, F. and Modabberi, S. (2009) Heavy Metal Contamination and Distribution in the Shiraz Industrial Complex Zone Soil, South Shiraz, Iran. World Applied Sciences Journal, 6, 413-425.

[14] Groom, C., Parker, J. and Teller, A. (1995) Agriculture. In: Stanners, E.D. and Bourdeau, P., Eds., Europe's Environment. The Dobris Assessment, European Environmental Agency (EEA), Copenhagen, 447-463.

[15] Alloway, B.J. (1990) Heavy Metal in Soils. John Wiley and Sons, New York, NY, USA.

[16] Shen, Z.-G., Li, X.-D., Wang, C.-C., Chen, H.-M. and Chua, H. (2002) Lead Phytoextraction from Contaminated Soil with High-Biomass Plant Species. Journal of Environmental Quality, 31, 1893-1900. https://doi.org/10.2134/jeq2002.1893

[17] Lu, Y., Song, S., Wang, R., Liu, Z., Meng, J., Sweetman, A.J., Jenkins, A., Ferrier, R.C., Li, H., Luo, W. and Wang, T. (2015) Impacts of Soil and Water Pollution on Food Safety and Health Risks in China. Environment International, 77, 5-15. https://doi.org/10.1016/j.envint.2014.12.010

[18] Mackay, A.K., Taylor, M.P., Munksgaard, N.C., Hudson-Edwards, K.A. and Burn-Nunes, L. (2013) Identification of Environmental Lead Sources and Pathways in a Mining and Smelting Town: Mount Isa, Australia. Environmental Pollution, 180, 304-311. https://doi.org/10.1016/j.envpol.2013.05.007

[19] Podolský, F., Ettler, V., Šebek, O., Ježek, J., Mihaljevič, M., Kř́bek, B., Sracek, O., Vaněk, A., Penížek, V., Majer, V., Mapani, B., Kamona, F. and Nyambe, I. (2015) Mercury in Soil Profiles from Metal Mining and Smelting Areas in Namibia and Zambia: Distribution and Potential Sources. Journal of Soils and Sediments, 15 648-658. https://doi.org/10.1007/s11368-014-1035-9

[20] Strzebońska, M., Jarosz-Krzemińska, E. and Adamiec, E. (2017) Assessing Historical Mining and Smelting Effects on Heavy Metal Pollution of River Systems over Span of Two Decades. Water, Air, and Soil Pollution, 228. https://doi.org/10.1007/s11270-017-3327-3

[21] Gochfeld, M. (2003) Cases of Mercury Exposure, Bioavailability, and Absorption. Ecotoxicology and Environmental Safety, 56, 174-179. https://doi.org/10.1016/S0147-6513(03)00060-5

[22] Haferburg, G. and Kothe, E. (2012) Biogeosciences in Heavy Metal-Contaminated Soils. In: Kothe, E. and Varma, A., Eds., Bio-Geo Interactions in Heavy Metal-Contaminated Soils, Springer, Heidelberg, 17-34. https://doi.org/10.1007/978-3-642-23327-2_2

[23] Brookes, P.C. and McGrath, S.P. (1984) Effect of Metal Toxicity on the Size of the Soil Microbial Biomass. European Journal of Soil Science, 35, 341-346. https://doi.org/10.1111/j.1365-2389.1984.tb00288.x

[24] Kumar, R.N. and Nagendran, R. (2007) Influence of Initial pH on Bioleaching of 
Heavy Metals from Contaminated Soil Employing Indigenous Acidithiobacillus thiooxidans. Chemosphere, 66, 1775-1781. https://doi.org/10.1016/j.chemosphere.2006.07.091

[25] Paz-Ferreiro, J., Lu, H., Fu, S., Méndez, A. and Gascó, G. (2014) Use of Phytoremediation and Biochar to Remediate Heavy Metal Polluted Soils: A Review. Solid Earth, 5, 65-75. https://doi.org/10.5194/se-5-65-2014

[26] Zhang, W.J., Jiang, F.B. and Ou, J.F. (2011) Global Pesticide Consumption and Pollution: With China as a Focus. Proceedings of the International Academy of Ecology and Environmental Sciences, 1, 125-144.

[27] Rodriguez-Eugenio, N., McLaughlin, M. and Pennock, D. (2018) Soil Pollution: A Hidden Reality. FAO, Rome, 142.

[28] WWAP (2017) The United Nations World Water Development Report, 2017: Wastewater: The Untapped Resource. United Nation Educational, Scientific and Cultural Organization, Paris. https://unesdoc.unesco.org/ark:/48223/pf0000247153

[29] Scott, C.A., Faruqui, N.I. and Raschid-Sally, L. (2004) Wastewater Use in Irrigated Agriculture: Management Challenges in Developing Countries. CABI Publishing, Wallingford, UK.

[30] WHO (2006) Guidelines for the Safe Use of Wastewater, Excreta and Greywater; Volume 2: Wastewater Use in Agriculture. World Health Organization, Geneva.

[31] Ensink, J., Mahmood, T., van der Hoek, W., Raschid-Sally, L. and Amerasinghe, F. (2004) A Nationwide Assessment of Wastewater Use in Pakistan: An Obscure Activity or a Vitally Important One? Water Policy, 6, 197-206. https://doi.org/10.2166/wp.2004.0013

[32] Lucke, B., al-Karaimeh, S. and Schörner, G. (2019) Channels, Terraces, Pottery, and Sediments-A Comparison of Past Irrigation Systems along a Climatic Transect in Northern Jordan. Journal of Arid Environments, 160, 56-73. https://doi.org/10.1016/j.jaridenv.2018.09.009

[33] Scheierling, S.M., Bartone, C.R., Mara, D.D. and Drechsel, P. (2011) Towards an Agenda for Improving Wastewater Use in Agriculture. Water International, 36, 420-440. https://doi.org/10.1080/02508060.2011.594527

[34] Van der Hoek, W., Hassan, M., Ensink, J.H., Feenstra, S., Raschid-Sally, L., Munir, S., Aslam, R., Ali, N., Hussain, R. and Matsuno, Y. (2002) Urban Wastewater: A Valuable Resource for Agriculture. A Case Study from Haroonabad, Pakistan. Research Report 63, IMWI, Colombo, Sri Lanka.

[35] Jiménez, B., Drechsel, P., Koné, D., Bahri, A., Raschid-Sally, L. and Qadir, M. (2010) Wastewater, Sludge and Excreta Use in Developing Countries: An Overview. Wastewater Irrigation, 1.

[36] Keraita, B., Jimenez, B. and Drechsel, P. (2008) Extend and Implications of Agricultural Reuse of Untreated, Partly Treated and Diluted Wastewater in Developing Countries. Agriculture, Veterinary Science, Nutrition and Natural Resources, 3, $1-15$.

[37] Raschid-Sally, L. and Jayakody, P. (2009) Drivers and Characteristics of Wastewater Agriculture in Developing Countries: Results from a Global Assessment. Research Report 127, IWMI, Colombo, Sri Lanka.

[38] del Estado, J. (2001) Plan Hidrológico Nacional. Boletín Oficialdel Estado, 24228-24250. https://www.boe.es/buscar/doc.php?id=BOE-A-2001-1304

[39] Keraita, B.N. and Drechsel, P. (2004) Agricultural Use of Untreated Urban Wastewater in Ghana. In: Scott, C.A., Faruqui, N.I. and Raschid-Sally, L., Eds., Wastewater Use in Irrigated Agriculture: Confronting the Livelihood and Environmental 
Realities, CABI, Wallingford, 101-112

http://www.cabi.org/cabebooks/ebook/20043115023

[40] Uzen, N. (2016) Use of Wastewater for Agricultural Irrigation and Infectious Diseases. Diyarbakir Example. Journal of Environmental Protection and Ecology, 17, 488-497.

[41] Moreira-Nodermann, L.M. (1987) Geochemistry and Environment. Geoquímica Brasilienses, 1, 89-107.

[42] Harter, R.D. (1983) Effect of Soil pH on Adsorption of Lead, Copper, Zinc, and Nickel. Soil Science Society of America Journal, 47, 47-51. https://doi.org/10.2136/sssaj1983.03615995004700010009x

[43] Sharma, M.R. and Raju, N.S. (2013) Correlation of Heavy Metal Contamination with Soil Properties of Industrial Areas of Mysore, Karnataka, India by Cluster Analysis. International Research Journal of Environment Sciences, 2, 22-27.

[44] Giller, K.E., Witter, E. and McGrath, S.P. (1998) Toxicity of Heavy Metals to Microorganism and Microbial Processes in Agricultural Soils: A Review. Soil Biology and Biochemistry, 30, 1389-1414. https://doi.org/10.1016/S0038-0717(97)00270-8

[45] Kozdrój, J. and van Elsas, J.D. (2001) Structural Diversity of Microbial Communities in Arable Soils of a Heavily Industrialized Area Determined by PCR-DGGE Finger Printing and FAME Profiling. Applied Soil Ecology, 17, 31-42. https://doi.org/10.1016/S0929-1393(00)00130-X

[46] Kurek, E. and Bollag, J.-M. (2004) Microbial Immobilization of Cadmium Released from CdO in the Soil. Biogeochemistry, 69, 227-239. https://doi.org/10.1023/B:BIOG.0000031046.40036.df

[47] Friedlová, M. (2010) The Influence of Heavy Metals on Soil Biological and Chemical Properties. Soil and Water Research, 5, 21-27. https://doi.org/10.17221/11/2009-SWR

[48] Möller, A., Müller, H.W., Abdullah, A., Abdelgawad, G. and Utermann, J. (2005) Urban Soil Pollution in Damascus, Syria: Concentrations and Patterns of Heavy Metals in the Soils of the Damascus Ghouta. Geoderma, 124, 63-71. https://doi.org/10.1016/j.geoderma.2004.04.003

[49] Lin, Y.P., Chang, T.K. and Teng, T.P. (2001) Characterization of Soil Lead by Comparing Sequential Gaussian Simulation, Simulated Annealing Simulation and Kriging Methods. Environmental Geology, 41, 189-199. https://doi.org/10.1007/s002540100382

[50] Van Meirvenne, M. and Goovaerts, P. (2001) Evaluating the Probability of Exceeding a Site-Specific Soil Cadmium Contamination Threshold. Geoderma, 102, 75-100. https://doi.org/10.1016/S0016-7061(00)00105-1

[51] Romic, M. and Romic, D. (2003) Heavy Metals Distribution in Agricultural Topsoils in Urban Area. Environmental Geology, 43, 795-805. https://doi.org/10.1007/s00254-002-0694-9

[52] McGraph, D., Zhang, C.S. and Carton, O. (2004) Geostatistical Analyses and Hazard Assessment on Soil Lead in Silvermines Area, Ireland. Environmental Pollution, 127, 239-248. https://doi.org/10.1016/j.envpol.2003.07.002

[53] Webster, R. and Oliver, M.A. (2007) Geostatistics for Environmental Scientists. 2nd Edition, John Wiley and Sons, Hoboken.

[54] Azawi, J., Husein, H.M.H. and Mousa, M. (2014) Mapping Soil Fertility of Beer El-Hashem Project-Raqqa Using GIS. Research Journal of Aleppo University, Agriculture Science Series 107. 
[55] Liu, X., Wu, J. and Xu, J. (2006) Characterizing the Risk Assessment of Heavy Metals and Sampling Uncertainty Analysis in Paddy Field by Geostatistics and GIS. Environmental Pollution, 141, 257-264. https://doi.org/10.1016/j.envpol.2005.08.048

[56] Zhang, C. and McGrath, D. (2004) Geostatistical and GIS Analyses on Soil Organic Carbon Concentrations in Grassland of Southeastern Ireland from Two Different Periods. Geoderma, 119, 261-275.

[57] Zhang, X.Y., Lin, F.F., Wong, M.T., Feng, X.L. and Wang, K. (2009) Identification of Soil Heavy Metal Sources from Anthropogenic Activities and Pollution Assessment of Fuyang County, China. Environmental Monitoring and Assessment, 154, 439. https://doi.org/10.1007/s10661-008-0410-7

[58] Abed Rabouh, R. (2005) The State of Rivers Pollution in Syria. MSc Thesis, Faculty of Agriculture, Damascus University.

[59] PKN (1998) Gleby I Utwory Mineralne. Pobieranie Próbek Ioznaczanie Składu Granulometrycznego PN-R-04032. Polski Komitet Normalizacyjny, Warszawa, ss.12.

[60] Nelson, D.W. and Sommers, L.E. (1982) Total Carbon, and Organic Matter. Methods of Soil Analysis, Part 2. Chemical and Microbiological Properties. Agronomy Monograph No. 9, 2nd Edition, ASA-SSSA, Madison, USA.

[61] Müller, G. (1979) Schwermetalle in den Sedimenten des Rheins-Veranderungen seit 1971. Umschau, 79, 778-783.

[62] Huu, H.H., Rudy, S. and Van Damme, A. (2010) Distribution and Contamination Status of Heavy Metals in Estuarine Sediments near CauOng Harbor, Ha Long Bay, Vietnam. Geology Belgica, 13, 37-47.

[63] Klerks, P.L. and Levinton, J.S. (1989) Rapid Evolution of Metal Resistance in a Benthic Oligochaete Inhabiting a Metal-Polluted Site. Biological Bulletin, 176, 135-141. https://doi.org/10.2307/1541580

[64] Sutherland, R.A. (2000) Bed Sediment-Associated Trace Metals in an Urban Stream, Oahu, Hawaii. Environmental Geology, 39, 611-627. https://doi.org/10.1007/s002540050473

[65] IPCC (1986) Principles and Methods for the Assessment of Neurotoxicity Associated with Exposure to Chemicals. World Health Organization, International Programme on Chemical Safety, Geneva (Environmental Health Criteria 60).

[66] Adeniyi, A.A., Yusuf, K.O. and Okedeyi, O.O. (2008) Assessment of the Exposure of Two Fish Species to Metals Pollution in the Ogun River Catchments, Kettu, Lagos, Nigeria. Environmental Monitoring and Assessment, 137, 451-458. https://doi.org/10.1007/s10661-007-9780-5

[67] Moreno, J.L., Bastida, F., Ros, M., Hernandez, T. and Garcia, C. (2009) Soil Organic Carbon Buffers Heavy Metal Contamination on Semiarid Soils: Effects of Different Metal Threshold Levels on Soil Microbial Activity. European Journal of Soil Biolo$g y, 45,220-228$. https://doi.org/10.1016/j.ejsobi.2009.02.004

[68] Yap, D.W., Adezrian, J., Khairiah, J., Ismail, B.S. and Ahmad-Mahir, R. (2009) The Uptake of Heavy Metals by Paddy Plants (Oryza sativa) in Kota Marudu, Sabah, Malaysia, American-Eurasian. Journal of Agriculture and Environmental Sciences, 6, 16-19.

[69] European Commission Director General Environment (2010) Heavy Metals and Organic Compounds from Wastes Used as Organic Fertilizers. Final Report, WPA Consulting Engineers Inc., Ref. Nr. TEND/AML/2001/07/20, 73-74. http://ec.europa.eu/environment/waste/compost/pdf/hm_finalreport.pdf 